\title{
Penerapan discovery learning untuk meningkatkan keaktifan dan hasil belajar materi program linear
}

\author{
Edy Suwanto \\ SMA Negeri 1 Karangrayung, Kabupaten Grobogan, Indonesia
}

\begin{tabular}{|c|c|}
\hline Article Info & ABSTRACT \\
\hline Article history: & \multirow{8}{*}{$\begin{array}{l}\text { This study aims to determine the increase in student activity and learning } \\
\text { outcomes in Linear Program material through the application of discovery } \\
\text { learning learning models. This research was conducted at SMA Negeri } 1 \\
\text { Karangrayung, Grobogan Regency, Central Java Province. This research } \\
\text { method uses classroom action research with two cycles. Each cycle consists of } \\
\text { four stages which include action planning, action implementation, observation } \\
\text { of action results, and reflection of action results. The results showed that the } \\
\text { average score of student learning activity in the initial conditions was } 27.67 \\
(=55.33 \%) \text { then in the first cycle was } 29.83 \text { ( }=59.67 \%) \text { and in the second cycle } \\
\text { was } 38.33(=76.67 \% \text {. While the average value of student learning outcomes } \\
\text { in the initial conditions was } 65.87 \text { then in the first cycle was } 68.77 \text { and in the } \\
\text { second cycle was } 75.50 \text {. The percentage of students' learning completeness in } \\
\text { the initial condition is } 10.00 \% \text {, then in the first cycle it is } 46.67 \% \text { and in the } \\
\text { second cycle it is } 96.67 \% \text {. Based on the results of the study, it can be } \\
\text { concluded that the discovery learning model can increase the activeness and } \\
\text { learning outcomes of students in the Linear Program material. }\end{array}$} \\
\hline Received : 25 Juli 2021 & \\
\hline Revised : 4 September 2021 & \\
\hline Accepted: 23 September 2021 & \\
\hline Keywords: & \\
\hline discovery learning; activity; & \\
\hline learning outcomes; linear & \\
\hline & \\
\hline
\end{tabular}

(*) Corresponding Author:

edykarangrayung11@gmail.com

How to Cite: Suwanto, E. (2021). Penerapan discovery learning untuk meningkatkan keaktifan dan hasil belajar materi program linear. Action Research Journal, 1(1): 40-46.

\section{PENDAHULUAN}

Matematika merupakan disiplin ilmu yang mendasari perkembangan teknologi modern, oleh karena itu matematika perlu diberikan kepada semua peserta didik untuk membekali peserta didik dengan kemampuan berpikir logis, analisis, sistematis, kritis dan kreatif, serta kempauan bekerja sama (Jamal, 2018). Hal ini sesuai dengan pendapat Soedjadi (2000) bahwa salah satu tujuan umum matematika adalah mempersiapkan peserta didik agar dapat menggunakan pola pikir matematika dalam kehidupan sehari-hari. Salah satu bentuk soal yang dapat digunakan untuk mengukur kemampuan peserta didik dalam pembelajaran matematika yaitu bentuk soal cerita (Raharjo \& Waluyati, 2011). Soal cerita biasanya diwujudkan dalam kalimat yang di dalamnya terdapat persoalan atau permasalahan yang penyelesaiannya menggunakan keterampilan berhitung (Budiyono, 2008). Berdasarkan hasil diskusi beberapa guru matematika di SMA Negeri 1 Karangrayung yang membahas permasalahan-permasalahan yang berhubungan dengan pelajaran matematika, disimpulkan bahwa salah satu materi matematika yang dirasa sulit oleh peserta didik kelas XI adalah program linear, hal ini disebabkan karena dalam materi program linear masalah-masalah yang disajikan berbentuk soal cerita.

Soal cerita matematika merupakan salah satu soal yang dapat digunakan untuk mengetahui keterampilan pemecahan masalah, karena sebagian besar soal cerita menghendaki siswa untuk menghubungkan situasi dunia nyata dengan konsep matematika (Seifi, Haghverdi \& Azizmohamadi, 2012). Situasi dunia nyata yang disajikan dalam soal cerita matematika biasanya berupa teks tanpa memuat notasi matematika (Boonen et al, 2016). Dalam memecahkan soal cerita matematika, peserta didik harus mampu memahami isi soal cerita, mengetahui obyek-obyek matematika yang harus diselesaikan, mampu mengubah atau 
menerjemahkan ke dalam model matematika, kemudian mampu memilih operasi hitung yang tepat dalam menyelesaikan soal ceria tersebut, sampai pada tahap akhir yaitu penyelesaian serta penarikan kesimpulan (Satoto, Sutarto \& Pujiastuti, 2013). Oleh karena itu penggunaan soal cerita dalam kegiatan belajar matematika dapat meningkatkan keterampilan peserta didik dalam menghubungkan antara materi matematika yang sudah dipelajari dengan situasi di kehidupan nyata (Angateeah, 2017). Kesulitan peserta didik dalam menyelesaikan soal cerita dapat menyebabkan terjadinya kesalahan dalam menyelesaikan soal cerita sehingga berpengaruh terhadap hasil belajar peserta didik. Hasil belajar mata pelajaran matematika peserta didik Kelas XI MIPA 5 SMA Negeri 1 Karangrayung Tahun Pelajaran 2019/2020 materi Induksi Matematika dari 30 peserta didik yang mengikuti penilaian harian, hanya 3 peserta didik yang tuntas, sedangkan yang tidak tuntas sebanyak 27 peserta didik. Persentase peserta didik yang tuntas sebesar 10,00\% dan yang tidak tuntas sebesar 90,00\%. Setelah dilaksanakan observasi tentang keaktifan belajar peserta didik, hasilnya hanya 2 peserta didik yang aktif sedangkan yang 28 peserta didik tidak aktif. Persentase peserta didik yang aktif sebesar 6,67\% dan yang tidak aktif sebesar $93,33 \%$.

Menurut Setyowati, Susilo \& Masrukan (2016) penyebab rendahnya hasil belajar matematika adalah kurang bervariasinya metode pembelajaran atau model pembelajaran yang diberikan guru. Oleh karena itu perlu dicarikan solusi dalam menentukan model pembelajaran yang tepat untuk materi berikutnya yaitu materi program Linear. Menurut Ula, Kristanti \& Mursyidah (2019) model discovery learning dapat meningkatkan peran aktif peserta didik dalam pembelajaran sehingga dapat meningkatkan hasil belajar peserta didik. Dengan menerapkan model pembelajaran discovery learning pada pembelajaran materi Program Linear diharapkan dapat meningkatkan keaktifan dan hasil belajar peserta didik. Hasil belajar digunakan untuk mengetahui seberapa jauh tujuan pendidikan dan pengajaran yang telah dikuasai. Hasil belajar adalah kemampuan peserta didik dalam menjawab tes penguasaan materi yang dipelajari (Anwar, 2019). Sedangkan Nuryadi \& Rahmawati (2018), mendefinisikan hasil belajar adalah perubahan yang mengakibatkan manusia berubah dalam sikap dan tingkah lakunya. Menurut Mulyasa (2010) hasil belajar peserta didik pada mata pelajaran matematika merupakan apa yang diperoleh peserta didik dari proses belajar matematika. Berdasarkan beberapa pengertian tentang hasil belajar tersebut di atas dapat disintesakan bahwa hasil belajar peserta didik pada mata pelajaran matematika adalah kemampuan peserta didik dalam menjawab tes penguasaan materi yang dipelajari melalui proses belajar matematika sehingga mengakibatkan perubahan sikap dan tingkah lakunya

Hasil belajar peserta didik pada mata pelajaran matematika diperoleh dari penilaian pengetahuan pada mata pelajaran matematika. Penilaian pengetahuan merupakan penilaian untuk mengukur kemampuan peserta didik berupa pengetahuan faktual, konseptual, prosedural, dan metakognitif, serta kecakapan berpikir tingkat rendah sampai tinggi. Penilaian pengetahuan, bertujuan untuk mengetahui sejauh mana peserta didik telah mencapai ketuntasan belajar, dan untuk mengidentifikasi kelemahan dan kekuatan penguasaan pengetahuan peserta didik dalam proses pembelajaran. Oleh karena itu, pemberian umpan balik kepada peserta didik sangat diperlukan, sehingga hasil penilaian dapat segera digunakan untuk perbaikan mutu pembelajaran.

Keaktifan dalam Kamus Bahasa Indonesia (2008) berarti kegiatan atau kesibukan, sedangkan belajar berarti berusaha memperoleh kepandaian atau ilmu. Dengan demikian pengertian keaktifan belajar adalah kegiatan yang dilakukan oleh seseorang untuk memperoleh kepandaian atau ilmu. Sedangkan menurut Rousseeou (dalam Rahmawati \& Permata, 2018) bahwa keaktifan belajar adalah segala pengetahuan yang diperoleh dengan pengamatan sendiri, dengan bekerja sendiri, dengan fasilitas yang diciptakan sendiri baik secara rohani maupun teknis. Keaktifan termasuk dalam sumber pembelajaran yang merupakan kombinasi antara suatu teknik dengan sumber lain. Sudjana (2008) menjelaskan bahwa indikator keaktifan peserta didik dapat dilihat dari indikator keaktifan, indikator keaktifan peserta didik dapat dilihat dari kriteria: (1) perhatian peserta didik terhadap penjelasan guru; (2) kerjasama antar peserta didik dalam 
kelompok; (3) kemampuan peserta didik dalam mengemukakan pendapat; (4) memberi kesempatan kepada peserta didik yang lain untuk berpendapat dalam kelompoknya; (5) mendengarkan dan memperhatikan dengan baik ketika ada anggota kelompok sedang berpendapat; (6) memberi ide atau gagasan yang cemerlang; (7) membuat pembagian tugas secara matang; (8) membuat keputusan dengan mempertimbangkan pendapat anggota kelompok yang lain; (9) memaksimalkan potensi anggota kelompok; serta (10) saling membantu dalam menyelesaikan masalah.

Menurut Bruner dalam Widyastuti \& Nurhamida (2017) model pembelajaran discovery learning atau penemuan adalah suatu proses yang dapat menjadi kemampuan umum pelajar melalui latihan pemecahan masalah. Sedangkan menurut Kurniasih \& Sani (2014) menjelaskan bahwa model pembelajaran discovery learning didefinisikan sebagai proses pembelajaran yang terjadi bila materi pembelajaran tidak disajikan dalam bentuk finalnya, tetapi diharapkan peserta didik mengorganisasi sendiri discovery learning merupakan suatu model pembelajaran untuk mengembangkan cara belajar aktif dengan menemukan sendiri, menyelidiki sendiri. Oleh karena itu hasil yang diperoleh melalui model pembelajaran discovery learning akan setia dan tahan lama dalam ingatan.

Model pembelajaran yang digunakan oleh guru mempunyai peran penting dalam proses pembelajaran (Ula, Kristanti \& Mursyidah, 2019). Dalam pembelajaran discovery (penemuan) kegiatan pembelajaran dirancang sedemikian rupa sehingga peserta didik dapat menemukan konsep-konsep dan prinsip-prinsip melalui proses mentalnya sendiri. Dalam proses menemukan konsep, peserta didik melakukan pengamatan, menggolongkan, membuat dugaan, menjelaskan, menarik kesimpulan dan sebagainya untuk menemukan beberapa konsep atau prinsip. Pada model pembelajaran discovery learning pendidik berperan sebagai pembimbing dengan memberikan kesempatan kepada peserta didik untuk belajar secara aktif, sebagaimana pendapat pendidik harus dapat membimbing dan mengarahkan kegiatan belajar peserta didik sesuai dengan tujuan. Dalam model pembelajaran discovery learning peserta didik dituntut untuk melakukan berbagai kegiatan menghimpun informasi, membandingkan, mengkategorikan, menganalisis, mengintegrasikan, mereorganisasikan bahan serta membuat kesimpulan.

Kurniasih dan Sani (2014) mengemukakan beberapa kelebihan dari model pembelajaran discovery learning, sebagai berikut: (1) Menimbulkan rasa senang pada peserta didik, karena tumbuhnya rasa menyelidiki dan berhasil. (2) Peserta didik akan mengerti konsep dasar dan ideide lebih baik. (3) Mendorong peserta didik berpikir dan bekerja atas inisiatif sendiri. (4) Peserta didik belajar dengan memanfaatkan berbagai jenis sumber belajar. Sedangkan Hosnan (2014) mengemukakan beberapa kekurangan dari model discovery learning yaitu: (1) menyita banyak waktu karena guru dituntut mengubah kebiasaan mengajar yang umumnya sebagai pemberi informasi menjadi fasilitator, motivator, dan pembimbing, (2) kemampuan berpikir rasional peserta didik ada yang masih terbatas, dan (3) tidak semua peserta didik dapat mengikuti pelajaran dengan model pembelajaran ini.

\section{METODE}

Penelitian tindakan kelas ini dilaksanakan di SMA Negeri 1 Karangrayung Kabupaten Grobogan Provinsi Jawa Tengah. Subjek penelitian ini adalah peserta didik kelas XI MIPA 5 SMA Negeri 1 Karangrayung Kabupaten Grobogan Tahun Pelajaran 2019/2020. Jumlah peserta didik kelas XI MIPA 5 sebanyak 30 orang, yang terdiri 9 laki-laki dan 21 perempuan. Pada pelaksanaan penelitian ini, peneliti berkolaborasi dengan 1 orang guru matematika. Penelitian ini dilaksanakan pada bulan Agustus 2019 sampai bulan November 2019. Kelas XI MIPA 5 merupakan salah satu kelas yang diampu peneliti. Materi Program linear merupakan materi Matematika Umum yang diberikan di kelas XI semester gasal. Metode pengumpulan data yang digunakan dalam penelitian ini berupa tes dan non tes. Metode pengumpulan data tes antara lain: (1) hasil penilaian harian pada siklus I, dan (2) hasil penilaian harian pada siklus II. Sedangkan metode pengumpulan data non tes dalam penelitian ini antara lain: (1) hasil observasi, (2) dokumentasi, dan (3) catatan lapangan. Indikator pencapaian atau kriteria 
keberhasilan pada penelitian ini sebagai berikut: (1) Kriteria keberhasilan pembelajaran dengan model pembelajaran pada tiap siklus sebesar 75\%. (2) Kriteria keberhasilan dari peningkatan keaktifan belajar peserta didik pada tiap siklus sebesar 31 atau 62\%. (3) Kriteria keberhasilan dari hasil belajar peserta didik pada siklus I dan siklus II sebesar $70 \%$ (sesuai $\mathrm{KKM}=70$ yang telah ditetapkan sekolah).

Pelaksanaan penelitian ini terdiri dari dua siklus, Adapun langkah-langkah atau tahaptahap tiap siklus terdiri: (1) perencanaan (planning), (2) pelaksanaan Tindakan (acting), (3) pengamatan (observing), dan (4) refleksi (reflecting). Refleksi merupakan suatu kegiatan mengulas secara kritis perubahan yang terjadi pada peserta didik, dan suasana pembelajaran di kelas. Pada tahap ini, pendidik menentukan langkah-langkah perbaikan untuk siklus selanjutnya. Kegiatan pada tahap perencanan, meliputi: (1) Permasalahan diidentifikasi dari data pada kondisi awal sebelum pelaksanaan penelitian kemudian permasalahan dirumuskan. (2) Pendidik (peneliti) dan observator (teman sejawat) berkolaborasi merencanakan untuk menerapkan model pembelajaran discovery learning. (3) pendidik membuat instrumen penelitian yang meliputi RPP, lembar observasi untuk pelaksanaan pembelajaran, lembar observasi untuk keaktifan belajar, dan soal penilaian harian siklus I dan kunci jawaban. Kegiatan pada tahap pelaksanaan, terdiri: (1) Kegiatan awal, antara lain: mengawali pelajaran dengan salam, observator mengamati jalannya kegiatan pembelajaran dan mengisi lembar observasi, pendidik melakukan apersepsi agar peserta didik siap menerima pembelajaran, pendidik menjelaskan tujuan dan manfaat pembelajaran, dan kompetensi yang akan dicapai setelah kegiatan pembelajaran. Selanjutnya membagi kelas menjadi beberapa kelompok yang masing-masing kelompok terdiri 4 orang. (2) Kegiatan Inti, antara lain: pendidik memberi Stimulation dengan membagikan lembar kerja, kemudian peserta didik sesuai dengan kelompoknya menyelesaikan lembar kerja. (3) Kegiatan Akhir (Penutup), terdiri: membuat simpulan, merefleksi kegiatan pembelajaran, mengisi daftar hadir, dan mengakhiri pelajaran dengan salam. Kegiatan pada tahap pengamatan yaitu: (1) Observator (pendidik sejawat) mengamati jalannya proses pembelajaran, mengisi lembar observasi. (2) Pendidik (peneliti) mengamati aktivitas peserta didik, baik secara individu maupun secara kelompok selama kegiatan pembelajaran berlangsung, dan pendidik membuat catatan lapangan untuk keperluan triangulasi data. Pada tahap refleksi, pendidik melakukan analisis terhadap hasil pengamatan selama proses pembelajaran. Selanjutnya hasil dari refleksi ini akan digunakan untuk memperbaiki pelaksanaan pembelajaran berikutnya. Hasil dari refleksi juga untuk pengambilan keputusan apakah penelitian dilanjutkan siklus berikutnya atau tidak.

\section{HASIL DAN PEMBAHASAN \\ Hasil}

Hasil observasi keaktifan belajar peserta didik pada siklus I seperti terlihat pada Tabel 1. Hasil penilaian harian pada siklus I yang selanjutnya digunakan sebagai alat ukur hasil belajar peserta didik pada siklus I, seperti terlihat pada Tabel 2. Sedangkan hasil observasi model pembelajaran discovery learning pada siklus I sebesar $72,5 \%$.

Tabel 1. Keaktifan belajar peserta didik pada siklus I

\begin{tabular}{|c|c|c|c|c|}
\hline Kategori & Rentang skor & Frekuensi & Persentase & Rata-rata Skor \\
\hline Aktif & $31-50$ & 8 & 26,67 & 29,83 \\
\hline Tidak Aktif & $11-30$ & 22 & 73,33 & $(=59,67 \%)$ \\
\hline \multicolumn{5}{|c|}{ Tabel 2. Hasil belajar peserta didik pada siklus I } \\
\hline Kategori & Rentang Nilai & Frekuensi & Persentase & $\begin{array}{c}\text { Rata-rata } \\
\text { Nilai }\end{array}$ \\
\hline Tuntas & $70-100$ & 14 & 46,77 & \multirow{2}{*}{68,77} \\
\hline Tidak Tuntas & $0-69$ & 16 & 53,33 & \\
\hline
\end{tabular}


Hasil observasi keaktifan belajar peserta didik pada siklus II seperti terlihat pada Tabel 3. Hasil penilaian harian pada siklus II yang selanjutnya digunakan sebagai alat ukur hasil belajar peserta didik pada siklus II, seperti terlihat pada Tabel 4. Sedangkan hasil observasi model pembelajaran discovery learning pada siklus II sebesar 85,00\%.

Tabel 3. Keaktifan belajar peserta didik pada siklus II

\begin{tabular}{lcccc}
\hline \multicolumn{1}{c}{ Kategori } & Rentang skor & Frekuensi & Persentase & Rata-rata Skor \\
\hline Aktif & $31-50$ & 27 & 90,00 & 38,33 \\
Tidak Aktif & $11-30$ & 3 & 10,00 & $(=76,67 \%)$ \\
\hline
\end{tabular}

Tabel 4. Hasil belajar peserta didik pada siklus II

\begin{tabular}{lcccc}
\hline \multicolumn{1}{c}{ Kategori } & Rentang Nilai & Frekuensi & Persentase & Rata-rata Nilai \\
\hline Tuntas & $70-100$ & 29 & 96,67 & 75,50 \\
Tidak Tuntas & $0-69$ & 1 & 3,33 & 7 \\
\hline
\end{tabular}

\section{Pembahasan}

Penerapan pembelajaran matematika materi Program Linear dengan menggunakan model pembelajaran Discovery Learning pada peserta didik Kelas XI MIPA 5 SMA Negeri 1 Karangrayung Grobogan Semester 1 Tahun pelajaran 2019/2020 berhasil meningkatkan keaktifan belajar peserta didik dan hasil belajar peserta didik sesuai dengan tujuan penelitian. Peningkatan keaktifan belajar dan hasil belajar pada mata pelajaran matematika khususnya materi Program Linear terlihat dari hasil observasi pada kondisi awal, siklus I dan siklus II.

Data hasil penelitian tentang keaktifan belajar peserta didik untuk kategori aktif yang semula pada kondisi awal sebanyak 2 orang $(6,67 \%)$, pada siklus I sebanyak 8 orang $(26,67 \%)$, kemudian pada siklus II menjadi 27 orang $(90,00 \%)$. Sedangkan untuk kategori tidak aktif yang semula pada kondisi awal sebanyak 28 orang $(93,33 \%)$, pada siklus I menjadi 22 orang $(73,33 \%)$, kemudian pada siklus II menjadi 3 orang $(10,00 \%)$. Persentase Keaktifan belajar peserta didik pada kondisi awal, siklus I dan siklus II dapat divisualisasikan dalam bentuk diagram seperti terlihat pada Gambar 1.

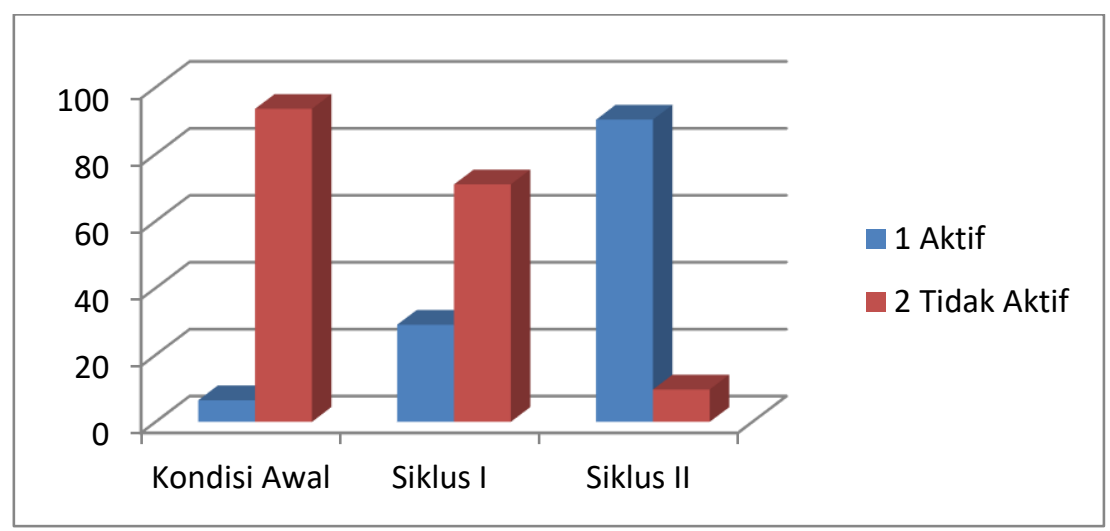

Gambar 1. Diagram persentase keaktifan belajar

Data hasil belajar peserta didik diperoleh dari hasil penilaian harian, baik pada kondisi awal, siklus I maupun siklus II. Data tentang ketuntasan hasil belajar peserta didik dalam kategori tuntas pada kondisi awal yang semula 3 orang (10,00\%), pada siklus I menjadi 14 orang $(46,67 \%)$, dan pada siklus II menjadi 29 orang $(96,67 \%)$. Sedangkan data peserta didik dalam kategori tidak tuntas pada kondisi awal yang semula 27 orang $(90,00 \%)$, pada siklus I menjadi 16 orang $(53,33 \%)$, dan pada siklus II menjadi 1 orang $(3,33 \%)$. Persentase ketuntasan 
belajar peserta didik pada kondisi awal, siklus I dan siklus II dapat divisulalisasikan dalam bentuk diagram seperti terlihat pada Gambar 2.

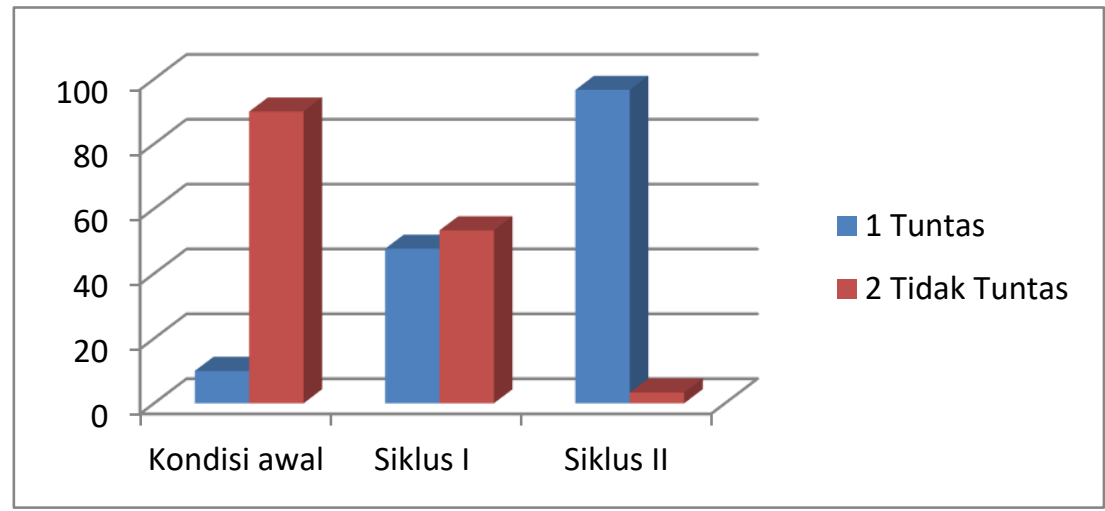

Gambar 2. Diagram persentase ketuntasan hasil belajar

\section{PENUTUP}

Berdasarkan hasil dan pembahasan dapat disimpulkan bahwa: (1) Pembelajaran dengan model discovery learning dapat meningkatkan keaktifan belajar peserta didik. (2) Pembelajaran dengan model discovery learning dapat meningkatkan hasil belajar peserta didik materi Program Linear. (3) Pembelajaran dengan model discovery learning di Kelas XI MIPA 5 SMA Negeri 1 Karangrayung Semester 1 Tahun Pelajaran 2019/2020 telah berjalan dengan baik dan lancar sehingga peserta didik dapat memahami materi Program Linear. Berdasarkan penelitian yang telah dilakukan dan hasil penelitian dapat dikemukakan saran-saran sebagai berikut (1) Pendidik agar menerapkan pembelajaran dengan model discovery learning sehingga peserta didik tidak jenuh. (2) Pendidik agar menerapkan model pembelajaran lain yang aktif, inovatif, kreatif, efektif dan menyenangkan. (3) Pendidik agar banyak membaca hasil-hasil penelitian untuk menambah wawasan.

\section{DAFTAR PUSTAKA}

Angateeah, K. S. (2017). An invesgation of students' difficulties in solving non-routine word problem at lower secondary. International Journal of Learning and Teaching, 3 (1).

Anwar, K., (2019). Peningkatan Aktivitas dan Hasil belajar Siswa SMA pada Dimensi Tiga Melalui Model Pembelajaran PBL Berbantuan Alat Peraga. Kreano: Jurnal Matematika Kreatif-Inovatif, 10 (1).

Boonen, A. J. H., De Koning, B. B., Jolles, J., \& Van Der Schoot, M. (2016). Word Problem Solving in Contemporary math Education: A Plea for Reading Comprehension Skills Training. Frontiers in Psychology. 7(1). DOI: https://doi.org/ 10.3389/ fpsyg.2016.00191.

Budiyono, B. (2008). Kesalahan Mengerjakan Soal Cerita dalam Pembelajaran Matematika. Paedagogia: Jurnal Penelitian Pendidikan, 11 (1).

Hosnan, M (2014). Pendekatan Saintifik dan Kontekstual dalam Pembelajaran Abad 21: Kunci Sukses Implementasi Kurikulum 2013. Bogor: Ghalia Indonesia.

Jamal, F. (2018). Analisis Kesalahan dalam Menyelesaikan Soal Cerita Pertidaksamaan Kuadrat Berdasarkan Prosedur Newman. Maju: Jurnal Ilmiah Pendidikan Matematika, 5(2).

Kemdendikbud. (2008). Kamus Bahasa Indonesia. Jakarta: Balai Pustaka.

Kurniasih \& Sani (2014). Panduan Membuat Bahan Ajar Buku Teks Pelajaran Sesuai dengan Kurikulum 2013. Surabaya: Pena.

Mulyasa. (2010). Penelitian Tindakan Kelas, Implementasi Kurikulum Tingkat Satuan Pendidikan Kemandirian Guru dan Kepala Sekolah, Jakarta: Bumi Aksara. 
Nuryadi \& Rahmawati, P. (2018), Persepsi Siswa Tentang Penerapan Model Pembelajaran Berbasis Proyek Ditinaju dari Kreativitas dan Hasil Belajar Siswa. Jurnal Mercumatika: Jurnal Penelitian Matematika dan Pendidikan Matematika, 3(1).

Raharjo, M \& Waluyati, A. (2011). Modul Matematika SD Program BERMUTU: Pembelajaran Soal Cerita Operasi Hitung Campuran di Sekolah Dasar. Pusat pengembangan dan Pemberdayaan Pendidik dan tenaga Kependidikan Matematika.

Rahmawati, D., \& Permata, L. D. (2012). Analisis Kesalahan Siswa dalam Menyelesaikan Soal Cerita Program Linear dengan Prosedur Newman. Jurnal Elektronik Pembelajaran Matematika, 5(2).

Satoto, S., Sutarto, H., \& Pujiastuti, E. (2013). Analisis Kesalahan Hasil Belajar Siswa dalam Menyelesaikan Soal dengan Prosedur Newman. Unnes Journal of Mathematics Education, 1 (2).

Seifi M., Haghverdi, M., \& Azizmohamadi, F. (2012). Recognition of Students Difficulties in Solving Mathematical Word Problems from The Viewpoint of Teachers Contextual and Conceptual Rewording View Project. Journal of Basic and Applied Scientific Research. $2(3)$.

Setyowati, N., Susilo, B., E. \& Masrukan. (2016). Penggunaan Alat Peraga untuk Meningkatkan Hasil Belajar dan Keaktifan Siswa pada Materi Peluang. Kreano: Jurnal Matematika Kreatif-Inovatif, 7 (1).

Soedjadi, S. (2000). Kiat Pendidikan Matematika di Indonesia. Direktorat Jendral Pendidikan Tinggi Departemen Pendidikan Nasional.

Sudjana (2008). Cara Belajar Peserta didik Aktif dalam Proses Belajar Mengajar. Bandung: Sinar Baru Algesindo.

Ula M., Kristanti, F. \& Mursyidah, H., (2019). Efektivitas Pembelajaran Discovery Learning Dengan Media Komik Pada Pembelajaran Garis dan Sudut di SMP Negeri 7 Surabaya. Jurnal Matematika dan Pendidikan Matematika, 4 (1).

Widyastuti, R., \& Nurhamida, F., (2017). Metode Discovery Learning Berbantuan Software Geogebra Untuk Meningkatkan Kemampuan Berfikir matematis mahasiswa politeknik Kediri. Jurnal Mercumatika: Jurnal Penelitian Matematika dan Pendidikan Matematika, 2 (1). 